\title{
EKONOMI SYARIAH \\ Kajian Pembiayaan Murabahah Antara Teori dan Praktek
}

Qi Mangku Bahjatulloh

\begin{abstract}
Abstrak
Pembiayaan murabahah telah mendominasi dalam penyaluran dana pada bank syari'ah, jumlahnya hampir mencapai tujuh puluh lima persen dari total pembiayaan, hal ini memunculkan kesan semua transaksi penyaluran dana bank syari'ah sengaja di murabahah-kan, kemungkinan untuk meminimalisir resiko yang akan menimpa bank dalam setiap penyaluran dananya. Dibandingkan dengan mekanisme-mekanisme pembiyaan yang lain, murabahah adalah yang paling menguntungkan dan paling sedikit resikonya terhadap bank syari'ah. Tulisan ini bertujuan untuk mereview dan mengkaji praktik pembiayaan murabahah dari konsep teori dan praktik.
\end{abstract}

Keywords: murabahah, ekonomi, perbankan, syariah, produk.

\begin{abstract}
s
Murabaha financing has dominated the distribution of funds in Shariah banks, nearly reaching seventy-five percent of the total financing. This impresses that all transactions of bank funding are done in murabaha system in order to minimize the risk that could happen to the bank. Compared to other finance mechanisms, murabaha is the most profitable and least risky to the Shariah banks. This study aims to review and assess the practice of murabaha financing in Islamic banking. This study is used as a reference for determining the validity of the concept of murabaha in Islamic Banking. By using descriptive and analytic method, it can be seen that in the increase of selling prices or determination of murabaha margin there are indications of gharar especially in determining the selling price that is higher than it should be.
\end{abstract}

Keywords: murabaha, shariah, product. 


\section{Pendahuluan}

Teori perbankan Islam, yang telah mulai berkembang sejak dekade 50-an, meneguhkan bahwa perbankan Islam adalah perbankan bebas bunga yang didasarkan pada konsep mudharabah dan musyarakah, yaitu konsep profit and loss sharing (PLS) atau bagi hasil (baik hasilnya berupa keuntungan atau kerugian). Para teoritis perbankan dan fuqaha muslim yang menyumbangkan teori ini, menafsirkan riba sebagai bunga (interest) dan keuntungan yang telah ditentukan sebelumnya atas modal, khususnya modal uang. (Abdullah Saeed, 2004: xiv).

Setelah lahirnya institusi Bank Islam yang melahirkan produk-produk pengganti bunga: mudharabah dan musyarakah, dan produk yang diasumsikan berdasarkan pada sistem bagi hasil, atau yang popular dikenal sebagai profit and loss sharing (PLS) dengan kedua produk itu, bank beroperasi tidak dengan bunga, tetapi dengan berbagi hasil bersama nasabah. Namun pada kenyataannya bank kemudian menyadari bahwa dua produk yang berbasis PLS itu sulit untuk diterapkan, dikarenakan resiko yang mungkin diterima oleh bank sangat tinggi, suatu resiko yang bersama dengan berjalannya waktu, telah memaksa bank untuk merenovasi bentuk dan isi mudharabah dan musyarakah hingga berbeda jauh dengan apa yang dapat ditemukan dalam fiqh. Oleh sebab itulah bank-bank Islam kemudian mencoba mencari alternatif, dimana bank-bank itu kemudian menemukan salah satu skim fiqh yang disebut dengan murabahah, hingga skim fiqh ini menjadi popular digunakan dalam perbankan syariah, karena bisnis ini nyaris tanpa resiko, dan digunakan oleh bank-bank Islam terbukti menduduki sampai $70 \%$ usaha Bank Islam dan meminimalisir posisi PLS hingga tinggal 30 sampai $0 \%$. (Abdullah Saeed, 2004:x)

Transaksi murabahah yang begitu mendominasi penyaluran dana pada bank syari'ah yang jumlahnya hampir mencapai tujuh puluh lima persen dari total pembiayaan dan adanya kesan bahwa semua transaksi penyaluran dana bank syari'ah dimurabahah-kan, kemungkinan untuk menekan seminimal mungkin resiko yang akan menimpa bank dalam setiap penyaluran dananya. Selain itu, dibandingkan dengan mekanisme-mekanisme pembiyaan yang lain, murabahah adalah yang paling menguntungkan dan paling sedikit resikonya terhadap bank syari'ah. 
Bank Syariah pada umumnya telah menggunakan murabahah sebagai metode pembiayaan yang utama, tentunya produk pembiayaan ini dianggap sangat signifikan dibanding pembiayaan-pembiayaan lain yang disediakan oleh Bank Syariah. Dominasi penggunaan pembiayaan murabahah dibandingkan prinsip PLS (musyarakah dan mudharabah) ini menunjukkan fenomena baru dalam praktik perbankan syariah di Indonesia.

Fenomena inilah yang melatar belakangi penulis untuk mengurai terhadap produk pembiayaan murabahah dalam prespektif fiqh, murabahah dalam perbankan syariah kritik terhadap aplikasi pembiayaan murabahah di perbankan syari'ah serta menawarkan konsep pricing dalam produk murabahah sebagai solusi alternative, dalam rangka mencapai tujuan pembumian ekonomi Islam di Indonesia. Mengingat semakin tingginya perkembangan produk pembiayaan murabahah di perbankan syariah saat ini, menuntut evaluasi praktik pembiayaan tersebut sesuai dengan hukum islam.

Diharapkan masa mendatang, perkembangan produk murabahah dalam perbankan syariah mampu menjadi pendorong terwujudnya perekonomian Indonesia yang kokoh, stabil dan adil. Disisi lain mampu menjadi perekat nasionalisme baru yang berpihak pada ekonomi kerakyatan, beroperasi secara transparan, berfungsi sebagai peningkatan efisiensi mobilisasi dana masyarakat, serta menjadi uswah hasanah bagi praktek usaha perbankan berlandaskan moral dan etika Islam.

\section{Pengertian Murabahah}

Secara etimologi murabahah berasal dari kata kerja rabiha-yarbahu yang bermakna untung (Abdul Qadir ar Raazi, 1995: 97) Sedangkan secara terminologi fiqh, murabahah adalah bentuk jual beli barang dengan menyatakan harga perolehan barang dan keuntungan margin yang ditentukan (Abdurrahman al Jaziry, 1999: 250). Murabahah adalah bentuk jual beli yang secara khusus masuk dalam bagian macam jual beli atau ba'i. dimana jual beli atau $b a$ 'I adalah proses transaksi (ijab dan qabul) atas perpindahan harta dengan harta yang sesuai dengan syariah. Sejalan dengan fase perkembangan madzhab fiqh, para ulama-ulama madzhab mulai berusaha mememberikan definisi murabahah secara tepat. 
Adalah madzhab Imam Maliki menjelaskan bentuk murabahah yang digambarkan, bahwa pemilik barang atau penjual menjelaskan kepada pembeli, perihal harga pokok pembelian, dan menjualnya kembali kepada pembeli dengan mengambil keuntungan yang ditentukan. Berbeda dengan Madzhab Imam Hanafi, dimana mendefinisikan murabahah sebagai perpindahan barang sesuai dengan kontrak dan harga yang disepakati diawal dengan menambahkan keuntungan yang disepakati. .(Wahbah Zuhaily, 1997:3765)

Sedangkan madzhab Imam Syafi'i dan Imam Hambali mendefinisikan Murabahah adalah sebagai proses jual-beli dengan harga pokok dengan menambahkan keutungan, dengan menambahkan persyaratan tertentu yaitu antara penjual dan pembeli harus mengetahui harga pokok awal. (Nawawi,1997:1382)

Meskipun secara definisi antara beberapa madzhab berbeda, namun kontrak murabahah sejak awal munculnya dalam fiqih, telah digunakan murni untuk tujuan dagang. (Abdullah Saeed, 2004: 119). Dan telah disepakati keabsahannya secara syariah oleh jumhur ulama dari kalangan sahabat, tabi'in dan para ulama madzhab, dengan berpijak pada landasan hukum syariah yang bersumber dari Al Quran dan Hadist nabi.

Menurut Abdullah Saeed (2004: 147) Murabahah adalah suatu jenis penjualan dengan pembayaran tunda dengan suatu transaksi perdagangan murni. Penjualan model ini diangap sah oleh para ulama walaupun tidak didukung oleh Al Qur'an dan Hadis. Bank-bank syari'ah menggunakan kontrak murabahah dalam aktifitas pembiayaan mereka. Pembiayaan semacam ini sekarang telah mencapai lebih dari tujuh lima persen dari total pembiayaan yang dilakukan oleh bank-bank syari'ah.

Syafi'I Antonio, (2001:101) menambahkan bahwa murabahah adalah jual beli barang pada harga asal dengan tambahan keuntungan yang disepakati. Dalam jual beli jenis ini, penjual harus memberitahu harga barang yang ia beli dan menentukan suatu tingkat keuntungan sebagai tambahannya.

Dengan memperhatikan dari pengertian-pengertian yang dikemukakan oleh para ulama di atas, dapat dipahami bahwa murabahah adalah menjual suatu barang dengan menegaskan harga belinya kepada pembeli dan pembeli membayarnya dengan harga lebih sebagai margin (keuntungan). Aplikasi pembiayaan murabahah pada bank syari'ah dapat digunakan untuk 
pembelian barang konsumsi maupun barang dagangan (pembiayaan tambah modal) yang pembayarannya dapat dilakukan secara tangguh (jatuh tempo/ angsuran). Bank syariah membeli barang yang diperlukan nasabah kemudian menjualnya kepada nasabah yang bersangkutan sebesar harga perolehan ditambah dengan margin keuntungan yang disepakati antara bank syariah dan nasabah. Satu hal yang membedakannya dengan cara penjualan yang lain adalah bahwa penjual dalam murabahah secara jelas memberi tahu kepada pembeli berapa nilai pokok barang tersebut dan berapa besar keuntungan yang dibebankannya pada nilai tersebut. Keuntungan tersebut bisa berupa lump sum atau berdasarkan persentase. Jika seseorang melakukan penjualan komoditi/barang dengan harga lump sum (cicilan) tanpa memberi tahu berapa nilai pokoknya, maka bukan termasuk murabahah, walaupun ia juga mengambil keuntungan dari penjualan tersebut. Penjualan ini disebut musawamah yaitu jual beli biasa di mana penjual tidak memberi tahu pembeli berapa jumlah keuntungan yang diambil.

\section{Praktek Murabahah dalam Bank Syariah}

Para pakar teori perbankan Islam telah mengemukakan bahwa perbankan Islam atau syariah lebih berdasar pada sistem bagi hasil atau pembagian untung rugi, tidak berdasarkan bunga. Namun demikian, bank-bank Islam dalam prakteknya, sejak awal meyakini bahwa perbankan yang berdasarkan PLS (Profit Loss Sharing) sulit untuk dilaksanakan karena sifatnya adalah sangat riskan dan tidak pasti.

Ada mekanisme yang sangat praktis yang menyertai pembiayaan ini menjadi penurunan secara bertahap dalam perbankan Islam, dan menyebabkan peningkatan yang tetap dalam penerapan mekanisme pambiayaan “menyerupai bunga".(Abdullah Saeed, 2003:136)

Idealnya, pembiayaan Bank Syariah didominasi oleh akad mudharabah (bagi hasil). Sebab, memang itulah ruh perbankan syariah. Namun, untuk sampai ke tahap itu tidak mudah. Bahkan di negara-negara yang sudah lebih dahulu menerapkan perbankan syariah pun, pembiayaan murabahah (jual-beli) masih dominan. Bank-bank Islam papan atas dunia, juga memiliki kecenderungan menjadikan skema murabahah sebagai skema pembiayaan yang utama. 
Bank Syariah dalam memberikan pelayanan pembiayaan kepada nasabahnya tidak hanya diselesaikan dengan cara mudharabah dan musyarakah (bagi hasil). Namun Bank Syariah dapat juga menjalankan pembiayaan dengan akad jual beli dan sewa. Pada akad jual beli dan sewa ini, pihak Bank Syariah akan memperoleh pendapatan secara pasti. Hal ini sesuai dengan konsep dasar teori pertukaran (Natural Certainty Contract), dimana kontrak dalam bisnis memberikan kepastian pembayaran baik dari segi jumlah maupun waktu, dalam bentuk ini cash flownya pasti atau telah disepakati di awal kontrak. Dan obyek penukarannya juga pasti secara jumlah, mutu, waktu maupun harganya. Kontrak bisnis yang masuk dalam kategori ini adalah kontrak bisnis tijarah dan ijarah. Sedangkan murabahah termasuk didalamnya dan telah dikembangkan oleh perbankan Syariah dalam pengembangan produk pembiayaannya.

Murabahah sebagaimana yang diterapkan dalam perbankan syari'ah, pada prinsipnya didasarkan pada 2 (dua) elemen pokok, yaitu harga beli serta biaya yang terkait dan kesepakatan atas mark-up. Ciri dasar kontrak pembiayaan murabahah adalah sebagai berikut: (Abdullah Saeed, 1996:77)

1. Pembeli harus memiliki pengetahuan tentang biaya-biaya terkait dan harga pokok barang dan batas mark-up harus ditetapkan dalam bentuk persentase dari total harga plus biaya-biayanya;

2. Apa yang dijual adalah barang atau komoditas dan dibayar dengan uang;

3. Apa yang diperjualbelikan harus ada dan dimiliki oleh penjual dan penjual harus mampu menyerahkan barang itu kepada pembeli;

4. Pembayarannya ditangguhkan.

Bank-bank syari'ah umumnya mengadopsi murabahah untuk memberikan pembiayaan jangka pendek kepada para nasabah guna pembelian barang meskipun mungkin nasabah tidak memiliki uang untuk membayar. Sejumlah alasan diajukan untuk menjelaskan popularitas murabahah dalam operasi investasi perbankan syari' ah, antara lain: (Abdullah Saeed, 1996:78)

1. Murabahah adalah suatu mekanisme investasi jangka pendek, dan dibandingkan dengan sistem Profit and Loss Sharing (PLS), cukup memudahkan; 
2. Mark-up dalam murabahah dapat diterapkan sedemikian rupa sehingga memastikan bahwa bank dapat memperoleh keuntungan yang sebanding dengan keuntungan bank-bank berbasis bunga yang menjadi saingan bank-bank Islam;

3. Murabahah menjauhkan ketidakpastian yang ada pada pendapatan dari bisnis-bisnis dengan sistem PLS;

4. Murabahah tidak memungkinkan bank-bank Islam untuk mencampuri manajemen bisnis, kerana bank bukanlah mitra si nasabah, sebab hubungan mereka dalam murabahah adalah hubungan antara kreditur dan debitur.

\section{Prosedur dan Syarat Pembiayaan Murabahah}

Produk pembiayaan murabahah ini dalam perkembangannya memegang kedudukan kunci nomor dua setelah prinsip bagi hasil dalam Bank Islam, dan dapat diterapkan dalam;

1). Pembiayaan perdagangan barang.

2). Pembiayaan pengeluaran Letter of Credit (L/C).

Murabahah ini juga akan sangat berguna sekali bagi seseorang yang membutuhkan barang secara mendesak tetapi kekurangan dana pada saat itu ia anggap kekurangan likuiditas. Ia meminta pada Bank agar membiayai pembelian barang tersebut dan bersedia menebusnya pada saat diterima. Harga jual pada pemesan adalah harga beli pokok plus margin keuntungan yang telah disepakati. (Warkum Sumitro, 1997: 38)

Untuk menjaga hal-hal yang tidak diinginkan, kedua belah pihak harus mematuhi prosedur ketentuan yang telah disepakati bersama. Adapun ketentuan dari pihak Bank, pihak Bank; harus mendatangkan barang yang benar-benar memenuhi pesanan nasabah baik secara jenis, kualitas, kuantitas ataupun sifat-sifat lainnya. Sedangkan bagi Pihak pemesan atau nasabah; apabila barang telah memenuhi ketentuan dan ia menolak untuk menebusnya, maka pihak bank berhak menuntutnya secara hukum, hal ini merupakan konsensus para juris muslim, karena pesanan telah dianalogikan dengan hutang (dhimmah) yang harus ditunaikan. 
Syafi'I Antonio (2002:102) menyatakan dalam menjalankan praktek murabahah ada beberapa persyaratan yang harus diperhatikan:

a. Penjual atau pihak bank harus memberi tahu biaya modal kepada nasabah

b. Kontrak pertama harus sah sesuai dengan rukun yang telah ditetapkan.

c. Kontrak harus bebas dari unsur riba

d. Penjual atau pihak bank harus menjelaskan kepada nasabah atau pembeli bila terjadi cacat atas barang sesudah pembelian

e. Penjual harus menyampaikan semua hal yang berkaitan dengan pembelian, misalnya jika pembelian dilakukan secara utang.

Secara prinsip jika syarat dalam poin (a), (d), atau (e) tidak dapat dipenuhi, maka pembeli atau nasabah memiliki pilihan:

a. Melanjutkan pembelian seperti adanya

b. Mengembalikan kepada penjual dan menyatakan ketidaksetujuan atas barang yang dijual

c. Membatalkan kontak

Dalam perbankan Islam praktek murabahah dapat dilakukan berdasarkan pesanan atau tanpa pesanan. Dalam murabahah berdasarkan pesanan, bank melakukan pembelian barang setelah ada pemesanan dari nasabah, dan dapat bersifat mengikat atau tidak mengikat nasabah untuk membeli barang yang dipesannya (bersifat mengikat bilamana bank meminta uang muka pembelian kepada nasabah). Misalnya seseorang ingin membeli mobil dengan perlengkapan tertentu yang harus dicari, dibeli, dan dipasang pada mobil pesanannya oleh dealer mobil. Dalam murabahah melalui pesanan ini diperbolehkan serta dianggap sah, dan si penjual boleh meminta pembayaran hamish ghadiyah, yaitu uang tanda jadi ketika transaksi atau ijab-qabul. Hal ini sekedar untuk menunjukkan bukti keseriusan si pembeli. Bila kemudian si penjual telah membeli dan memasang berbagai perlengkapan di mobil pesanannya, sedangkan si pembeli membatalkannya, hamish ghadiyah ini dapat digunakan untuk menutup kerugian dealer mobil. Dan bila uang jadi ini lebih kecil dibanding jumlah kerusakan yang harus ditanggung oleh si penjual, penjual dapat meminta kekurangannya. Sebaliknya bila berlebih, si pembeli berhak atas kelebihan itu. Dalam murabahah 
yang berdasarkan pesanan yang bersifat mengikat, pembeli tidak dapat membatalkan pesanannya. (Adiwarman Karim, 2003:163).

Sistem pembayaran yang dilakukan oleh perbankan syariah dalam praktek murabahah ini dapat dilakukan secara tunai atau cicilan. Dalam murabahah juga diperkenankan adanya perbedaan dalam harga barang untuk cara pembayaran yang berbeda. Murabahah muajjal dicirikan dengan adanya penyerahan barang diawal akad dan pembayaran kemudian (setelah awal akad), baik dalam bentuk angsuran maupun dalam bentuk lump sum (sekaligus). Bank juga dapat memberikan potongan apabila nasabah;

a). Mempercepat pembayaran cicilan atau,

b). Melunasi piutang murabahah sebelum jatuh tempo.

Berdasarkan sumber dana yang digunakan, pembiayaan murabahah secara garis besar dapat dibedakan menjadi tiga kelompok:

a. Pembiayaan murabahah yang didanai dengan URIA (Unrestricted Investment Account $=$ Investasi tidak terikat)

b. Pembiayaan murabahah yang didanai dengan RIA (Restricted Investment Account $=$ Investasi terikat)

c. Pembiayaan murabahah yang didanai dengan modal Bank

Dalam setiap pendesainan sebuah pembiayaan, faktor-faktor yang perlu diperhatikan adalah: kebutuhan nasabah terhadap barang dan kemampuan finansial nasabah. Faktor-faktor ini juga akan mempengaruhi sumber dana yang akan digunakan untuk pembiayaan tersebut. (Adiwarman Karim, 2003:164)

\section{Ketentuan Umum Dalam Pembiayaan Murabahah}

\section{a. Jaminan}

Meminta jaminan atas uang pada dasarnya bukanlah sesuatu yang tercela, dan jaminan bukanlah satu rukun atau syarat yang mutlak dipenuhi dalam murabahah. Namun demikian meminta jaminan dipandang oleh para pendukung perbankan Islam sebagai suatu penghambat dalam aliran dana bank untuk para pengusaha kecil, bank-bank Islam cenderung mengkritik 
bank-bank konvensional sebagai bank yang terlalu berorientasi jaminan (security oriented). Bagi Bank Islam jaminan bukanlah hal yang penting dalam putusan pembiayaan. (Muhammad, 2003: 248)

Meskipun demikian kontrak-kontrak murabahah dalam bank-bank Islam tetap menggunakan jaminan, bahkan bank-bank Islam seperti Faisal Islamic Bank, Jordan Islamic Bank telah memuat klausul-klausul yang menekankan pentingnya jaminan. Dalam hal ini jaminan dimaksudkan untuk menjaga agar pemesan tidak main-main dengan pesanan. Pihak bank dapat meminta kepada pemesan suatu jaminan (rahn) untuk dipegangnya. Namun dalam teknis operasionalnya, barang-barang yang dipesan dapat menjadi salah satu jaminan yang bisa diterima untuk pembayaran.(Muhammad Syafi'I Antonio, 2002:105)

\section{b. Utang Dalam Murabahah}

Secara prinsip, penyelesaian utang si pemesan dalam transaksi murabahah pesanan atau yang sering disebut dalam istilah perbankan syariah dengan murabahah KPP (Kepada Pemesan Pembelian) tidak ada kaitannya dengan transaksi lain yang dilakukan si pemesan kepada pihak ketiga atas barang pesanan tersebut. Apakah si pemesan menjual kembali barang tersebut dengan keuntungan atau kerugian, ia tetap berkewajiban menyelesaikan utangnya kepada si pembeli.

Jika pemesan menjual barang tersebut sebelum masa angsurannya berakhir, ia tidak wajib segera melunasi seluruh angsurannya. Seandainya penjual aset tersebut merugi, contohnya kalau nasabah adalah pedagang juga, pemesan harus tetap menyelesaikan pinjamannya sesuai kesepakatan awal. Hal ini dikarenakan transaksi penjualan kepada pihak ketiga yang dilakukan nasabah merupakan akad yang benar-benar terpisah dari akad murabahah pertama dengan bank (Muhammad Syafi'I Antonio, 2002:105)

\section{c. Penundaan Pembayaran Oleh Debitor Mampu}

Seorang nasabah yang mempunyai kemampuan secara ekonomis dilarang menunda penyelesaian utangnya dalam murabahah. Moral hazard ini sering terjadi dalam praktek pembiayaan murabahah di Perbankan Syariah. 
Jika seorang pemesan menunda penyelesaian utang tersebut, pembeli atau pihak bank dapat mengambil tindakan dengan mengambil prosedur hukum untuk mendapatkan kembali utang itu dan mengajukan klaim kerugian finansial yang terjadi akibat penundaan.

Dalam contoh praktek di BRI Syariah jika ada nasabah yang ngempalang dalam pembayaran murabahah maka pihak bank cenderung mengambil jalan kekeluargaan, namun jika memang nasabah tidak bisa membayar dalam tempo yang telah ditentukan dan masih mempunyai kemampuan membayar (unable), adapun jika nasabah tidak mau membayar atau ngemplang, maka pihak Bank dapat melakukan penyitaan asset lewat KP2LN (Kantor Pengurusan Piutang dan Lelang Negara) oleh karena itu pihak Bank selalu berhati-hati sebelum melangsungkan aqad dengan melakukan cara-cara yang tidak mengurangi rasa kepercayaan Bank terhadap nasabah, antara lain :

- Pihak bank bisa memperhitungkan kemampuan nasabah dalam membayar cicilan, dan mengetahui latar belakang nasabah, sebab pihak bank menempuh jalan in demi menjaga amanat nasabah lainnya.

- Dalam melakukan transaksi aqad bank melibatkan Notaris Syariah, hal ini ditempuh untuk mendapatkan legalitas hukum.

Prosedur dan mekanisme penyelesaian sengketa antara Bank Syariah dan nasabahnya telah diatur melalui Badan Arbitrase Muamalah Indonesia (BAMUI), yaitu suatu lembaga yang didirikan bersama antara Kejaksaan Agung Republik Indonesia dan Majelis Ulama Indonesia. (Muhammad Syafi'I Antonio, 2002:106)

Dalam hadits, Rasulullah ditegaskan bahwa pengutang yang mampu tetapi sengaja menunda pembayaran maka akan mendapatkan sanksi hukum. (Bukhari, hadits: 2225)

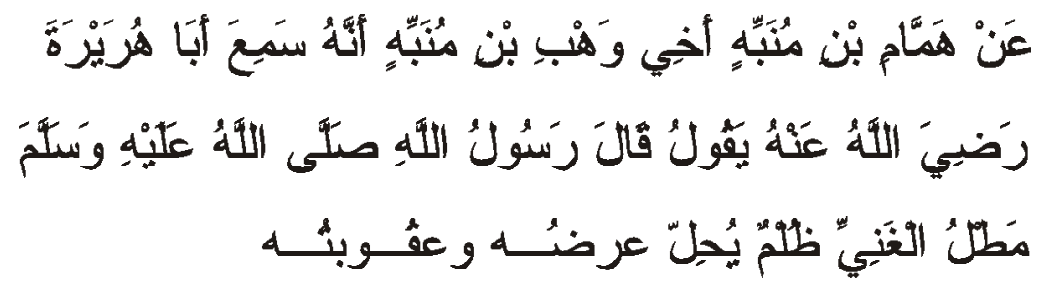


Namun jika pemesan yang berutang dianggap pailit dan gagal menyelesaikan hutangnya karena benar-benar tidak mampu secara ekonomi dan bukan karena lalai sedangkan ia mampu, kreditor harus menunda tagihan utang sampai ia benar-benar sanggup kembali. Hal ini sesuai dengan firman Allah:

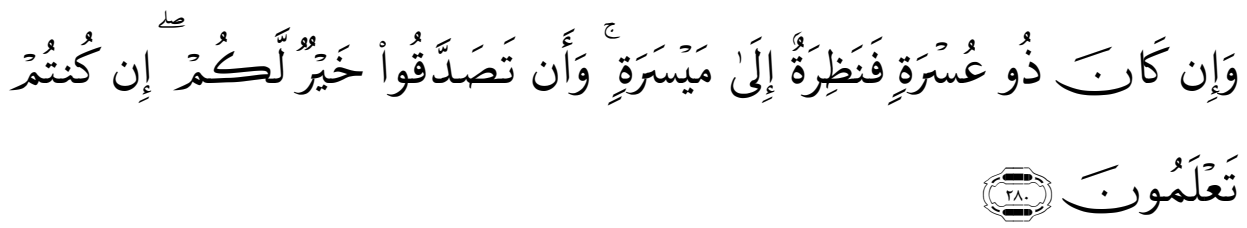

Dan jika (orang yang berhutang itu) dalam kesukaran, Maka berilah tangguh sampai Dia berkelapangan. dan menyedekahkan (sebagian atau semua utang) itu, lebih baik bagimu, jika kamu mengetahui.(Al Baqarah:280)

\section{Aplikasi Dan Manfaat Pembiayaan Murabahah}

Pada umumnya pembiayaan murabahah dengan sisem pesanan dapat diterapkan pada produk pembiayaan untuk pembelian barang-barang investasi, baik domestik maupun luar negeri, seperti melui Letter of Credit (L/C). Skema ini paling banyak digunakan karena sederhana dan tidak asing dalam dunia perbankan pada umumnya.

Namun kalangan perbankan di Indonesia lebih banyak menggunakan pembiayaan murabahah secara berkelanjutan (roll over/evergreen), seperti untuk pembiayaan modal kerja, padahal sebenarnya murabahah adalah kontrak jangka pendek dengan sekali akad (one short deal). (M. Syafi'I Antonio, 2002:106) Hal ini tidaklah tepat jika diterapkan untuk skema pembiayaan modal kerja. Namum akad mudharabah yang lebih sesuai, mengingat prinsip mudharabah memiliki fleksibilitas yang sangat tinggi.

Sesuai dengan sifat bisnis tijarah, transaksi pembiayaan murabahah memiliki beberapa manfaat, demikian juga resiko yang harus diantisipasi. Pembiayaan dengan sistem murabahah ini banyak memberikan manfaat kepada Bank Syariah. Salah satunya adalah adanya keuntungan yang muncul dari selisih harga beli dari penjual dengan harga jual kepada nasabah. Selain 
itu, sistem murabahah ini juga sangat sederhana, sehingga dapat memudahkan pihak perbankan dalam penanganan administrasinya di Bank Syariah

Menurut Syafi'I Antonio (2002: 107) ada kemungkinan resiko yang harus diantisipasi antara lain sebagai berikut:

a. Default atau kelalaian, yang dibuat oleh nasabah sengaja tidak membayar angsuran dimana ia mampu secara ekonomis.

b. Fluktuasi harga komparatif, hal ini dapat terjadi bila harga suatu barang di pasar naik setelah bank membelikannya untuk nasabah. Dimana bank tidak bisa mengubah harga jual beli tersebut kepada nasabah.

c. Penolakan barang yang dilakukan oleh nasabah; barang bisa saja dikembalikan atau ditolak oleh nasabah karena berbagai sebab. Hal ini bisa jadi disebabkan karena rusak dalam perjalanan sehingga nasabah tidak mau menerimanya. Oleh karena itu, sebaiknya dilindungi dengan asuransi. Kemungkinan lain nasabah merasa spesifikasi barang tersebut tidak sesuai atau berbeda dengan yang ia pesan. Bila bank telah menandatangani kontrak atau aqad pembelian dengan penjualnya, maka barang tersebut akan menjadi milik Bank. Dengan demikian Bank mempunyai resiko untuk menjualnya kepada pihak lain.

d. Barang dijual; karena murabahah bersifat jual beli dengan utang, maka ketika kontrak ditandatangani, barang itu menjadi hak milik nasabah penuh, dan nasabah bebas untuk mrelakukan apapun terhadap aset miliknya, termasuk menjualnya. Jika terjadi demikian maka resiko untuk default akan besar.

\section{Kritik dan Permasalahan Murabahah di Perbankan Syariah}

Maraknya perbankan syari'ah tak lepas dari kritik dan kecaman, yang justru datang dari para ilmuwan Islam sendiri. Mereka berpendapat bahwa bank-bank syari' ah dalam menyelenggarakan transaksi-transaksi perbankan syari'ah justru telah melaksanakannya bertentangan dengan konsepnya. Dengan kata lain, bertentangan dengan semangat dari prinsip-prinsip syari'ah. Penerapan usahausaha bisnis bank syari'ah, terutama produk murabahah telah menimbulkan masalah moralitas. Dari pengamatan dan penelitian beberapa ilmuwan Islam itu, bank-bank syari'ah, dalam penerapan 
produk-produknya ternyata bukannya meniadakan bunga dan membagi resiko, tetapi tetap mempertahankan praktek pembebanan bunga dengan menggunakan label islam.

Meskipun banyak kritik yang diarahkan kepada praktek murabahah di perbankan syari'ah, namun hal ini justru mengindikasikan bahwa sebenarnya produk murabahah ini direspon secara luas. Oleh karena itu, dalam perjalanannya para teoritisi dan praktisi perbankan syari'ah masih terus melakukan kajian dan mengkritisi secara serius mekanisme kontrak murabahah yang sesuai dengan semangat dari prinsip-prinsip syari'ah dalam rangka mencapai tujuan pembumian ekonomi syari'ah di Indonesia.

Namun dari indikator pengawasan dan pemeriksaan yang dilaporkan BI, terbukti masih ditemui berbagai sistem operasional perbankan yang sistemnya belum sesuai dengan prinsip-prinsip syariah. Berkaitan dengan penerapan prinsip-prinsip syariah dalam kegiatan operasional bank, maka peran Dewan Pengawas Syariah (DPS) sangatlah penting dan sangatlah dibutuhkan. Hal ini bertujuan untuk untuk menjamin penerapan prinsip syariah atau sharia quality insurance.

Untuk itu Bank Syariah harus dapat beroperasi secara konsisten dengan prinsip syariahnya. Bank syariah yang mengabaikan hal ini, akan menghadapi risiko reputasi atau reputational risk yang bermuara pada kekecewaan masyarakat. Dewan Pengawas Syariah (DPS), berfungsi untuk menjaga kemurnian prinsip syariah. Peran DPS masih perlu ditingkatkan lagi. Hal itu bertujuan agar Bank Syariah secara konsisten dan sekaligus dapat meminimalkan risiko yang berkaitan dengan citra perbankan syariah. Demikian pula dengan peran Dewan Syariah Nasional Majelis Ulama Indonesia (DSN MUI) juga menjadi sangat penting. Untuk menjaga purifikasi Bank Syariah, Bank Indonesia perlu melakukan kajian tentang standardisasi akad, dan penyempurnaan dalam hal regulasi maupun pengawasan perbankan syariah.

Hal lain Perbankan Syariah sangat memerlukan Undang-Undang tersendiri yang terpisah dari Undang-Undang Perbankan Konvensional. Saat ini, pembahasan tentang Undang-Undang Perbankan Syariah itu masih terus dikaji. Undang-undang tersendiri itu diharapkan dapat menjadi payung tidak hanya untuk sektor perbankan, tapi juga pasar modal. Demi terwujudnya 
perekonomian perbankan Indonesia yang kuat, sehat dan rahmatan lil alamiin.

\section{Kenaikan harga jual dalam Murabahah dan Tawaran konsep Pricing}

Barangkali banyak yang beranggapan bahwa ada kesamaan antara praktek pembiayaan murabahah di bank syari'ah dengan profit margin-nya dengan pembiayaan kredit di bank konvensional dengan bunga-nya. Untuk itu, kita perlu mengkaji serta menganalisis pembiayaan berbasis murabahah.

Bank konvensional dalam meminjamkan uang, misalnya untuk pembelian barang-barang tertentu, bunga yang dikenakan pada pinjaman dikaitkan dengan pokok pinjaman dan jatuh tempo pinjaman. Sedangkan berapa harga barang nasabah itu bukanlah menjadi urusan bank konvensional. Hal utama yang menjadi perhatian bank konvensional adalah memperoleh suku bunga yang sedang berlaku bagi pengeluran-pengeluaran, semisal dalam hal resiko dan jatuh temponya.

Dalam mekanisme pembiayaan murabahah di bank syari'ah, nasabah dapat mengetahui total harga barang sebelumnya, dimana hal ini tidak akan diketahui dalam pembiayaan berbasis bunga. Dalam murabahah, faktor-faktor yang tampaknya mempengaruhi besarnya mark-up adalah kebutuhan bank syari'ah untuk memperoleh keuntungan riil,inflasi, suku bunga berjalan, kebijakan moneter, dan marketabilitas barang-barang murabahah serta tingkat laba yang diharapkan dari barang-barang itu. Dengan demikian, mark-up dalam murabahah bisa saja lebih tinggi atau lebih rendah dari suku bunga. (Muhammad, 2004: 103)

Namun, nampaknya, menurut penulis, perbedaan antara mark up murabahah di bank syari'ah dengan suku bunga dalam pinjaman kredit di bank konvensional ini tidak terlalu jauh. Hal inilah yang memicu munculnya persepsi masyarakat yang menyamakan praktek murabahah di bank syari'ah dengan pinjaman kredit di bank konvensional. Untuk itu, perlu adanya konsep yang jelas dalam penentuan harga jual (pricing) murabahah.

Para fuqaha sepakat tidak terlalu mempersoalkan keabsahan jual beli pembayaran tunda pada harga tunai. Namun perbedaaan pendapat dikalangan ulama terjadi pada harga kredit yang lebih tinggi (sebagai lawan dari 
harga tunai) dalam jual beli dengan pembayaran tunda.

Menurut Imam Malik dan Imam Syafi'I tidak menyetujui harga kredit yang lebih tinggi untuk jual beli dengan pembayaran tunda dan harga harga yang lebih rendah untuk pembayaran tunai, sebagaimana yang disebutkan dalam bukunya al-Muwatha' Imam Malik dan al-Umm Imam Syafi'i tentang jual beli dengan pembayaran tunda. Hal ini juga tidak diketemukan satu pendapatpun dari ulama' ini yang membolehkan jual beli suatu barang berdasarkan murabahah dengan harga kredit yang lebih tinggi daripada harga kontannya.(As Syafi"I, III:31-35)

Meskipun perbedaan pendapat muncul, beberapa ulama fiqh seperti Ibnu Qudamah, Imam Nawawi, Marghinani dan Sarakhsi secara tegas menyatakan bahwa pengenaan harga yang lebih tinggi pada jual beli kredit adalah praktik yang biasa dalam perdagangan.(Muhammad,2003:240)

Dalam Perbankan Islam, pengenaan harga yang lebih tinggi pada jual beli kredit dianggap sah. Dalam konteks transaksi dengan kenaikan harga, ada beberapa argumen yang mendukung keabsahan suatu harga yang lebih tinggi dalam penjualan dengan pembayaran di tunda, antara lain adalah: (Abdullah Saeed, 1996: 79)

a) Bahwa teks-teks syariah secara tegas tidak ada pernyataan larangan pengenaan harga yang lebih tinggi pada jual beli tunda.

b) Ada perbedaan antara uang yang tersedia sekarang dengan yang tersedia dimasa mendatang.

c) Kenaikan harga bukanlah alasan sebagai imbalan waktu tunda pembayaran, karenanya tidak sama dengan riba pra-Islam yang diharamkan dalam al-Quran.

d) Kenaikan harga ini dikenakan pada saat penjualan bukan setelah penjualan terjadi.

e) Kenaikan harga didasarkan pada faktor-faktor yang mempengaruhi pasar seperti faktor demand dan supply, dan kenaikan atau penurunan dalam pembelian nilai mata uang sebagai akibat inflasi atau deflasi.

Argumen diatas yang selalu diajukan oleh Bank-Bank Islam untuk melegalkan praktek kenaikan harga pada jual beli dengan pembayaran tunda yang secara jelas terkait dengan jangka waktu uang. Bank-bank Islam sudah 
barang tentu menerima keabsahan kenaikan harga tersebut, dan ini telah menjadi praktek baku untuk mengenakan harga yang lebih tinggi dalam jual beli dengan pembayaran tunda selama transaksinya secara eksplisit tidak mengandung tukar menukar uang dengan uang.

Pada masa modern, para kritikus murabahah, berpendirian bahwa kenaikan harga karena waktu adalah riba. Council Of Islamic Ideology (CII) Pakistan juga menyatakan bahwa keraguan mungkin muncul dalam kaitannya dengan tambahan yang diterima penjual dalam hal jual beli dengan pembayaran tunda (sebagai pengganti tenggang waktu pembayaran yang diberikan untuk pembeli) dan, kerenanya tambahan semacam ini dapat menyerupai riba. Akan tetapi, Bank-Bank Islam dan mereka yang mendukung penggunaan praktek murabahah dalam perbankan Islam seperti Mohammed (1989), Saleh (1986), International Association of Islamic Bank (IAIB) Syahata (1987) tidak menganggap kenaikan dalam harga kredit memiliki kemiripan dengan riba. (Muhammad, 2003:241)

Dalam lingkungan keuangan modern, para sarjana ekonomi tampaknya menganggap bahwa riba adalah sesuatu yang selalu terjadi, terutama pada utang, yaitu dalam praktek tukar menukar uang dengan uang. Mereka berpendapat bahwa dalam suatu hutang, setiap bentuk kewajiban kontraktual untuk membayar suatu tambahan adalah riba, dengan menganggap bahwa tambahan seperti itu sebagai pengganti tenggang waktu pembayaran utang. Sedangkan Islam telah mengharamkan tambahan apapun yang melebihi dan diatas pokok pinjaman.

Barangkali karena merasa ada semacam kemiripan antara kenaikan harga dalam murabahah dengan tambahan yang diberikan kepada kreditur sebagai imbalan perpanjangan waktu jatuh tempo hutang (yang dalam beberapa hal mirip dengan riba yang telah diharamkan oleh Al-Qur'an), sebagian sarjana Muslim berusaha menghindari setiap pengkaitan antara kenaikan harga dalam murabahah dengan tenggang waktu untuk pembayaran. Menurut salah seorang ekonom dari Mesir, Husein Syahata, kenaikan itu bukanlah karena tenggang waktu pembayaran. Jika demikian halnya, maka adanya harga yang lebih rendah untuk pembayaran tunai, dan harga yang lebih tinggi untuk pembayaran tunda tidaklah penting. (Muhammad, 2003:242) 
Ibrahim Warde juga mengkritisi tentang skema kenaikan harga yang berkaitan low risk dan sorth term dengan bagi resiko antara bank Islam dengan peminjam, dimana kecenderungan resiko yang mungkin dialami bank selalu minimal, sedangkan determinasi marjin profit selalu meningkat.( Ibrahim Warde, 2001:134) Dengan adanya kenaikan harga jual atau penentuan margin murabahah disinilah mulai ditemukan indikasi praktek gharar dalam penentuan harga jual yang lebih tinggi dalam pembayaran tunda.

Praktek murabahah dalam perbankan syariah seharusnya tidak hanya menjadikan tingkat suku bunga sebagai rujukan utama dalam penentuan harga jual produk murabahah, cara ini dianggap tidak tepat untuk mengantisipasi kenaikan suku bunga di pasar atau inflasi. Dimana jika terjadi kenaikan suku bunga bank syariah tidak rugi, namun jika suku bunga di pasar stabil atau turun maka margin murabahah akan lebih besar dibanding bank konvensional.

Penetapan harga jual murabahah, sebaiknya dapat dilakukan dengan cara Rasulullah ketika berdagang. Cara ini dapat dipakai sebagai salah satu metode bank syari' ah dalam menentukan harga jual produk murabahah. Cara Rasulullah dalam menentukan harga penjualan adalah menjelaskan harga belinya, berapa biaya yang telah dikeluarkan untuk setiap komoditas dan berapa keunt ungan wajar yang diinginkan. Cara penetapan harga jual tersebut berdasarkan cost plus mark up.( Slamet Wiyono. 2005:89)

Berdasarkan fakta di atas, menurut Muhamamad (2005:140) maka perlu dirumuskan formula baru dalam menentukan kenaikan harga jual, agar pembiayaan murabahah itu terbebas dari unsur gharar, yaitu:

Harga jual bank $=$ Harga Beli Bank + Cost Recovery + Keuntungan

Cost Recovery $=\frac{\text { Dana Pembiayaan }}{\text { Target Volume Pembiayaan }} \times$ Biaya operasional

Margin dalam prosentase $=\frac{\text { Cost Recovery }+ \text { Keuntungan }}{\text { Harga beli bank }} \times 100 \%$

Cost Recovery adalah bagian dari estimasi biaya operasi bank syari'ah yang dibebankan kepada harga beli/total pembiayaan. Cost Recovery bisa 
dengan membagi proyeksi biaya operasional bank, dengan target volume pembiayaan murabahah di bank syariah. Angka ini dapat diperoleh dari Rapat Kerja dan Anggaran Perusahaan (RKAP), kemudian ditambahkan dengan harga beli dari pemasok dan keuntungan yang diinginkan, sehingga didapat harga jual. Margin dalam kontek ini adalah Cost Recovery ditambah dengan keuntungan bank. Apabila margin ingin dihitung secara prosentase tinggal dibagi dengan harga beli dan dikalikan 100\%.

Setelah angka-angka didapat, barulah prosentase margin dibandingkan dengan suku bunga. Jadi suku bunga hanya dijadikan benchmark. Agar murabahah lebih kompetitif, margin murabahah harus lebih kecil dari bunga pinjaman. Dan jika masih besar maka haruslah memperkecil cost recovery dan keuntungan yang diharapkan. Langkah petama adalah menurunkan keuntungan. Jika keuntungan sudah turun sampai batas minimalnya, dan ternyata marginnya masih lebih besar dari bunga bank, maka tentu ada yang tidak besar dari cost recovery. Artinya, efisiensi bank tersebut rendah. Efisiensi yang rendah dapat ditingkatkan dengan mengurangi biaya operasional pada target volume pembiayaan yang sama. Efisiensi juga dapat dicapai dengan memperbesar target volume pembiayaan pada biaya operasional yang sama. Hal ini dapat dicapai dengan cara meningkatkan kualitas SDM bank syariah. Lebih baik jika pengurangan biaya operasional dilakukan bersamaan dengan meningkatkan volume pembiayaan. Efisiensi tinggi akan segera diperoleh, cost recovery semakin kecil dan keuntungan perbankan meningkat walaupun dengan margin murabahah yang lebih kecil dari bunga pinjaman bank konvensional. (Muhammad,2003:258)

\section{Penut up}

Murabahah adalah jual beli di mana penjual memberitahu pembeli biaya perolehan dan keuntungan yang diinginkannya. Murabahah dalam fiqih awalnya tidak berhubungan dengan pembiayaan. Dengan berkembangnya pemikiran, murabahah digunakan oleh perbankan syari'ah dengan menambahkan beberapa konsep lain sehingga menjadi bentuk pembiayaan.

Pembiayaan murabahah yang begitu mendominasi penyaluran dana pada bank syari'ah yang jumlahnya hampir mencapai tujuh puluh lima persen 
dari total pembiayaan memunculkan kesan semua transaksi penyaluran dana bank syari'ah sengaja di murabahah-kan, kemungkinan meminimalisir resiko yang akan menimpa bank dalam setiap penyaluran dananya. Dibandingkan dengan mekanisme-mekanisme pembiyaan yang lain, murabahah adalah yang paling menguntungkan dan paling sedikit resikonya terhadap bank syari'ah.

Perbankan Islam beranggapan bahwa Al Qur'an menghalalkan segala macam perdagangan, yaitu jual beli dengan laba, dan murabahah termasuk jual beli dengan laba. Mengingat tidak ada pembatasan dalam jumlah tertentu atas keuntungan yang diperoleh dari suatu perdagangan, maka bank-bank syari'ah secara teori dengan bebas menentukan berapapun mark-up (keuntungan) dari kontrak murabahah.

Label 'Syari'ah' yang dimiliki oleh perbankan, tidaklah cukup untuk menjadi suatu syarat menjadi bank syari'ah. Institusi perbankan, baik yang Syari'ah atau yang tidak syariah, perlu menjadi institusi yang lebih memikirkan kemaslahatan ummat. Ekonomi yang mencerminkan keadilan dan kemanusiaan.

Rumusan konsep pricing dalam kontrak pembiayaan murabahah diharapkan mampu mencerminkan nilai syari'ah dalam aplikasinya di perbankan syari'ah. Dengan harapan hadirnya bank syari'ah di tengah-tengah kita diharapkan mampu memecahkan segala problem ekonomi umat dengan payung Syari'ah

\section{Daftar Pustaka}

.Al Qur'an al Karim (Saudi Arabia: Majma' al Malik Fahd)

Al Bukhari, Al Jami' As Shahih, (Beirut: Darul Fikr)

Abdullah Saeed, PhD. Menyoal Bank Syariah, Kritik Atas Interpretasi Bunga Bank Kaum Neo-Revivalis (Jakarta, Paramadiana 2004)

Abdullah Saeed, Bank Islam dan Bunga, (Yogyakarta: Pustaka Pelajar 2003) Abdullah Saeed, (1996), Islamic Banking and Interest, A Study of Prohibition of riba

and its contemporary Interpretation, Leiden: E.J. Brill.

Abdul Mannan, Islamic Economic, Theory and Practice, Terj. M. Nastangin (Yogyakarta: Dana Bhakti Wakaf 1995) 
Adi Nugroho, Faktor-Faktor Yang Mempengaruhi Margin Pembiayaan Murabahah(Studi Kasus pada PT. Bank Muamalat Indonesia periode Januari 2001 sampai dengan Desember 2004), diakses dari http:// www.pskttiui.com/indonesia/abstrakalumni.php?id= 7102910028

Abdurrahman al Jaziry, Kitab al Fiqh 'Ala Madzahib al Arba'ah (Beirut: Dar al Kutub al Ilmiyah, 1999)

Abdul Qadir ar Raazi, Muhtar as Shihah (Lebanon: Maktabah Lubnan Naasyirun 1995)

Adiwarman Karim, Bank Islam, Analisis Fiqih dan Keuangan (Jakarta: IIIT Indonesia 2003)

'Alauddin Abi Bakar Al Kasani, Al Badai'i (Mesir: Matba'ah al Ilmiyah.1327 $\mathrm{H})$.

Al Kaff. Does Islam Assign Any Value (Karachi: Islamic Research Academy)

Al Kasani, Kitab Bada'I as Sana'i fi Tartib asy Syara' (Beirut: Darul Fikr 1996)

Arrison Hendry, Perbankan Syariah Prespektif Praktisi (Jakarta: Muamalah Institute 1999)

Anita Rahmawaty, Kontroversi Status Keabsahan Murabahah Dalam Perbankan Syariah; Telaah Atas Penerapan Produk Di Bank Muamalah Semarang (Perpustakaan IAIN Yogyakarta, 2000)

Ascarya, Akad dan Produk Bank Syari'ah, Jakarta: PT Raja Grafindo, 2007 Bukhari, Shahih Bukhari (Beirut: Darul Fikr)

DPbS BI dan P3EI-UII, Teks Book Ekonomi Islam,Yogyakarta,UII, 2007.

DSN MUI, Himpunan Fatwa Dewan Syari'ah Nasional, Ed. III,Jakarta, 2006.

Ibn Abidin, Radd al Muhtar ala ad Durr al Muhtar (Beirut: Dar Ihya at Turas al Arabi. 1987)

Ibnu Majah, Sunan Ibnu Majah, Kitab Tijaraat, (Beirut: Darul Fikr)

Ibrahim Warde, Islamic Finance in the Global Media (Edinburgh: Edinburgh University Press 2001)

Imam Muhammad Ismail Al Kakhalani, Subulus Salam, (Beirut: Darul Fikr) Irfan Syauqi Beik, Artikel Kajian Ekonomi Islam, www.pesantrenvirtual.com Ibrahim Warde, Islamic Finance in The Global Media (Edinburgh: Edinburgh University Press 2001

Iswantono, Henricus W., Kamus Istilah Ekonomi Populer, Jakarta: Kompas Media Nusantara, 2003.

Karnaen Perwataatmadja dan M. Syafi'i Antonio, Apa dan Bagaimana Bank Islam, (Yogyakarta: PT. Dana Bhakta Wakaf, 1997) 
Latifa M.Algoud dan Mervyn K. Lewis, Perbankan Syariah: Prinsip, Praktik Dan Prospek (Jakarta: Serambi Ilmu Semesta, 2003) terjemah, Burhan Wirasubrata

Malik bin Anas, Al Muwattha' (Mesir: Isa Al Halabi 1951)

Muhammad, Lembaga Keuangan Umat Kontemporer, (Yogyakarta: UII Press 2000)

Muhammad, Manajemen Bank Syariah (Yogyakarta: UPP AMP YKPN 2002)

Muhammad Syafi'I Antonio, Bank Syariah Dari Teori Ke Praktek (Jakarta, Gema Insani Press 2002)

Muhammad Ibnu Ahmad Ibnu Muhammad Ibnu Rusyd, Bidayatul Mujtahid (Beirut: Dar al- Qalam)

Muhammad, Bank Syariah Analisis Kekuatan, Kelemahan, Peluang, dan Ancaman, (Yogyakarta, EKONISIA 2002)

Muhammad. 2004. Teknik perhitungan bagi hasildan profit margin pada Bank Syariah,Syariah. Yogyakarta: UII Press.

Muhammad as Syarbini, Mughni Muhtaj (Mesir: Matba'ah Albani Halbi, 1933)

Muhammad bin Idris As-Syafi'i, Al Umm (Mesir: Maktabah Maemuniah)

Muhammad, Manajemen Dana dan Pembiayaan Bank Syariah 2003 (diktat kuliah)

Muslim, Shahih Muslim, (Mesir: Isa al Halbi)

Nawawi, Raudhah at Thalibin (Beirut: Darul Fikr)

Nawawi, Muhadzab (Beirut: Darul Fikr) Cet. III

Nejatullah Siddiqi, Partnership and Profit Sharing in Islamic Law, terj. Fakhriyah Mumtihani (Yokyakarta: Dana Bhakti Prima Yasa 1996)

Slamet Wiyono. 2005. Akuntansi Perbankan Syari'ah. Jakarta: PT. Grasindo.

Sayyid Sabiq, Fiqhus Sunah, (Beirut: Darul Kitab al Arabi 1978)

Umar Chapra, Towards a Just Monetary System, (Yogyakarta: Dana Bhakti Wakaf 1997)

Umar Chapra,, Sistem Moneter Islam, terj. Ikhwan Abidin Basri, Jakarta, Gema Insani

Press, 2005.

Warkum Sumitro, Asas-Asas Perbankan Islam Dan Lembaga-Lembaga

Terkait Di Indonesia (Jakarta, Raja Grafindo Persada, 1997)

Wahbah Zuhaily, al Fiqh al Islami wa Adillatuhu (Beirut: Darul Fikr 1997)

Wahbah Zuhaily, Al Muamalah Al Maliyah Al Mu'asyirah (Beirut: Daarul Fikr 2002) 
Website resmi Bank Syariah Mandiri www. syariahmandiri.co.id Zainal Arifin, Memahami Bank Syariah (Jakarta, Alvabet. 1999)

Zainal Arifin, Dasar-Dasar Manajeman Bank Syari'ah (Jakarta: Alfabeta, 2002)

Zaim Saidi, Penelitian Praktek Perbankan Syariah (Jurnal Muamalah Oktober 2003) Vol I No. I 